\title{
Low-temperature plasma treatment induces DNA damage leading to necrotic cell death in primary prostate epithelial cells
}

\author{
A M Hirst ${ }^{1}$, M S Simms ${ }^{2,3}$, V M Mann ${ }^{2,3}$, N J Maitland ${ }^{4}$, D O'Connell ${ }^{1}$ and F M Frame ${ }^{\star, 4}$ \\ ${ }^{1}$ York Plasma Institute, Department of Physics, University of York, Heslington, York YO10 5DD, UK; ${ }^{2}$ Department of Urology, Castle \\ Hill Hospital, Cottingham, East Yorkshire HU16, 5JQ, UK; ${ }^{3}$ Hull York Medical School, University of Hull, Hull, East Yorkshire \\ HU6 7RX, UK and ${ }^{4}$ YCR Cancer Research Unit, Department of Biology, University of York, Heslington, York YO10 5DD, UK
}

Background: In recent years, the rapidly advancing field of low-temperature atmospheric pressure plasmas has shown considerable promise for future translational biomedical applications, including cancer therapy, through the generation of reactive oxygen and nitrogen species.

Method: The cytopathic effect of low-temperature plasma was first verified in two commonly used prostate cell lines: BPH-1 and PC-3 cells. The study was then extended to analyse the effects in paired normal and tumour (Gleason grade 7) prostate epithelial cells cultured directly from patient tissue. Hydrogen peroxide $\left(\mathrm{H}_{2} \mathrm{O}_{2}\right)$ and staurosporine were used as controls throughout.

Results: Low-temperature plasma (LTP) exposure resulted in high levels of DNA damage, a reduction in cell viability, and colonyforming ability. $\mathrm{H}_{2} \mathrm{O}_{2}$ formed in the culture medium was a likely facilitator of these effects. Necrosis and autophagy were recorded in primary cells, whereas cell lines exhibited apoptosis and necrosis.

Conclusions: This study demonstrates that LTP treatment causes cytotoxic insult in primary prostate cells, leading to rapid necrotic cell death. It also highlights the need to study primary cultures in order to gain more realistic insight into patient response.

Despite continual improvement and refinement, long-term treatment for prostate cancer $(\mathrm{PCa})$ is still recognised as inadequate (Jemal et al, 2011). In the case of early onset, organ-confined tumours, patients may be treated with a focal therapy (Kasivisvanathan et al, 2013; Donaldson et al, 2014). Radiotherapy or photodynamic therapy (PDT), which rely on the production of reactive oxygen species (ROS) for cytotoxic effects, are two treatments of choice for localised PCa. However, around a third of patients will experience recurrence of their disease following radiotherapy (Jones, 2011). This may be due to inherent radio-resistance of a small fraction of the tumour - the cancer stem-like cells (Frame et al, 2013). Furthermore, numerous side effects are often experienced following treatment (Chen et al, 2007; Lips et al, 2008), even with more recent technological developments, such as stereotactic body radiation therapy (Cyberknife) (Woo et al, 2014).
In recent years, low-temperature plasmas (LTPs) have shown considerable potential as active agents in biomedicine. They are formed by applying a high electric field across a gas, which accelerates electrons into nearby atoms and molecules, leading to a cascade effect of multiple ionisation, excitation and dissociation processes. This creates a complex and unique reactive environment consisting of positive and negative charges, strong localised electric fields, UV radiation, reactive species, and mainly background neutral molecules.

Operated at atmospheric pressure and around room temperature, LTPs produce high concentrations of reactive oxygen and nitrogen species (RONS), including but not limited to: atomic nitrogen (Wagenaars et al, 2012) and oxygen (Knake et al, 2008; Waskoenig et al, 2010; Niemi et al, 2013), hydroxyl (OH) (Ninomiya et al, 2013), singlet delta oxygen (SDO) (Sousa et al, 2011), superoxide (Kang et al, 2014), and nitric oxide (NO) (Ma et al, 2014). It is now widely

*Correspondence: Dr FM Frame; E-mail: fiona.frame@york.ac.uk

Received 18 November 2014; revised 29 January 2015; accepted 3 March 2015; published online 2 April 2015

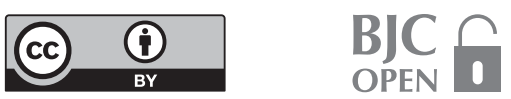


believed that the principal mode of plasma-cell interaction is the delivery of RONS, a key mediator of oxidative damage and cell death in biological systems (Wiseman and Halliwell, 1996; Bandyopadhyay et al, 1999), generated in the plasma and transferred to target source (Graves, 2012, 2014).

In contrast, cell death by PDT relies on the generation of ROS, specifically SDO, which is highly cytotoxic (Sharman et al, 1999). Nonetheless, strong treatment resistance is encountered in hypoxic tumour regions (Krzykawska-Serda et al, 2014). The limitations of both radiotherapy and PDT, combined with the fact that LTPs concurrently produce both a multitude of RONS (Murakami et al, 2013) known to be toxic to cells and potentially strong localised electric fields, promotes the potential of LTP as a future cancer therapy, which we have recently reviewed (Hirst et al, 2014b).

Many studies now describe the effects of LTPs on various cancer cell lines in culture, with reported effects including reduced cell viability (Cheng et al, 2014; Plewa et al, 2014), growth arrest (Chang et al, 2014), and apoptotic cell death (Keidar et al, 2011; Gibson et al, 2014; Ishaq et al, 2014). We have reported induction of DNA damage by application of LTP treatment to primary prostate epithelial cells (Hirst et al, 2014a). Recent in vivo studies also revealed that LTP treatment of subcutaneous tumours (grown from cell lines) induced growth arrest and cell death, thus significantly reducing tumour volume in glioblastoma cells (Vandamme et al, 2012). Another study showed that short, daily exposure of tumours (squamous cell carcinoma) to LTP causes DNA damage leading to apoptosis (Kang et al, 2014). Internal treatment with LTP has also been explored using an endoscopic approach to application (pancreatic and colorectal cells), which demonstrated reduced tumour volume and also invasion capacity (Robert et al, 2013). However, the penetrative capability of LTP treatment through solid tissues leading to complete tumour eradication is yet to be established in vivo.

Here we first conducted a proof-of-principle study in order to validate the cytopathic effect of LTP treatment on two commonly used prostate cell lines derived from benign disease (BPH-1) and prostate cancer metastasis (PC-3). We then analysed in detail the effect of LTP treatment on a matched pair of primary samples. We cultured prostate epithelial cells from normal prostate and prostate cancer tissue (Gleason grade 7) retrieved from biopsies from a single patient, allowing for direct comparison of the effects of LTP on both normal and cancer cells. We present the first experimental evidence that LTP may be a suitable candidate for focal therapy treatment of patients with early onset prostate cancer through the induction of high levels of DNA damage, leading to a substantial reduction in colony-forming capacity, and ultimately necrotic cell death, in clinically relevant and close-to-patient samples.

\section{MATERIALS AND METHODS}

Culture of cell lines and primary prostate epithelial cells. Two prostate cells lines were used in this study: BPH-1 cells, derived from benign prostatic hyperplasia (BPH), and PC-3 cells, derived from PCa bone metastases. BPH-1 cells were cultured in RPMI 1640 medium supplemented with 5\% foetal calf serum (FCS) and $1 \%$ L-glutamine. PC-3 cells were cultured in Ham's F12 medium, supplemented with $7 \%$ FCS and 1\% L-glutamine. No antibiotic or antimycotics were added to the cell culture medium. Cells were incubated at $37^{\circ} \mathrm{C}$ with $5 \% \mathrm{CO}_{2}$.

Primary prostate epithelial cells were cultured from human tissue samples as described previously (Collins et al, 2005). Needle core biopsies ( $14 \mathrm{~g}$ ) were taken immediately following surgical removal of the prostate. The site of each biopsy was determined by previous pathology, imaging, and palpation. Tissues were transported in RPMI-1640 with 5\% FCS and $100 \mathrm{Uml}^{-1}$ antibiotic/antimycotic solution at $4{ }^{\circ} \mathrm{C}$ and processed within $6 \mathrm{~h}$. Needle core biopsies were verified as normal or Gleason grade 7 cancer by subsequent pathology, both cores originating from the same patient undergoing radical prostatectomy. Samples were obtained with full ethical permission and patient consent. Primary cells were cultured in stem cell media, based on keratinocyte serum-free media supplemented with L-glutamine, stem cell factor, granulocyte macrophage colony stimulating factor, cholera toxin, bovine pituitary extract, epidermal grown factor and leukaemia inhibitory factor (Collins et al, 2005). Significantly, these cells are cultured in media without FCS. Cells were grown on collagen-Icoated $10-\mathrm{cm}$ dishes in the presence of irradiated STO feeder cells and incubated at $37{ }^{\circ} \mathrm{C}$ with $5 \% \mathrm{CO}_{2}$. No antibiotic or antimycotics were added to the cell culture medium.

LTP jet configuration and characterisation. The LTP jet consisted of a quartz glass tube of inner/outer diameter $4 / 6 \mathrm{~mm}$, with two copper tape electrodes spaced $20 \mathrm{~mm}$ apart (Figure 1A). One electrode was powered $(6 \mathrm{kV}$ sinusoidal voltage at $30 \mathrm{kHz})$ and one grounded. Helium was used as a carrier gas at 2 standard litres per minute (SLM), fed with $0.3 \%$ molecular oxygen admixture. Cells were exposed to the LTP jet at a distance $15 \mathrm{~mm}$ from the end of the bottom electrode for a range of treatment times from 0 to $600 \mathrm{~s}$ in centrifuge tubes in a volume of $1.5 \mathrm{ml}$ media. The distance between the end of the glass tube and the media surface was $\sim 2 \mathrm{~mm}$. Hydrogen peroxide $\left(\mathrm{H}_{2} \mathrm{O}_{2}\right.$, Fisher Scientific, Loughborough, UK) was used throughout as a positive cytoxicity control at a concentration of $1 \mathrm{~mm}$. Using a thermocouple, treatment times of up to $600 \mathrm{~s}$ did not raise the surface temperature of culture media above $36.5^{\circ} \mathrm{C}$. The temperature and relative humidity of the laboratory were $\sim 20^{\circ} \mathrm{C}$ and $\sim 25 \%$ respectively.

Optical emission spectroscopy was performed using an Ocean Optics HR4000CG-UV-NIR spectrometer (Dunedin, FL, USA) (200-1100 nm range) and the Spectra suite analysis software (Dunedin, FL, USA). Integration time and scans to average were set at 6 and $50 \mathrm{~s}$, respectively. A background dark spectrum was obtained and subtracted from subsequent spectra. The optical fibre was aligned directly with the core plasma region and fixed at $\sim 2 \mathrm{~cm}$ from the quartz tube.

Cell viability and clonogenic recovery assays. Cell viability was determined by use of the alamarBlue assay (Invitrogen, Life Technologies Ltd, Paisley, UK). Cells were treated with LTP and then plated into black-walled 96-well plates in triplicate at a density of 5000 cells per well in $100 \mu \mathrm{l}$ of media. At $24,48,72$, and $96 \mathrm{~h}$ after treatment, $10 \mu \mathrm{l}$ of alamarBlue reagent (DAL1025, Invitrogen) was added to each well and incubated for $2 \mathrm{~h}$ at $37^{\circ} \mathrm{C}$. Fluorescence was recorded at excitation/emission values of 544/590 nm using a microplate reader (Polarstar Optima, BMG Labtech, Aylesbury, Bucks, UK), with cell viability recorded against normalised untreated samples.

Clonogenic recovery assays were used to measure cellular recovery posttreatment. Cells were treated in suspension and replated in six-well plates in triplicate at a density of 200 disaggregated cells per well. Cells were supplemented with $2 \mathrm{ml}$ of growth media, which was changed every other day. In the case of primary epithelial cell cultures, STO feeder cells were also added. At 12 days after treatment, plates were stained with crystal violet (PBS, $1 \%$ crystal violet, $10 \%$ ethanol). Only colonies of $>50$ cells (equating to $>5$ population doublings) were counted (Francipane et al, 2008).

DNA damage. LTP-induced DNA damage was quantified using the alkaline comet assay (adapted from Sturmey et al, 2009). Cells were treated with LTP in $1.5 \mathrm{ml}$ centrifuge tubes at a density of 20000 cells in $1.5 \mathrm{ml}$ media suspension. Immediately after treatment, cells were resuspended in $30 \mu \mathrm{l}$ PBS and mixed with $225 \mu \mathrm{l}$ low melting point agarose. This was then pipetted onto microscope slides 

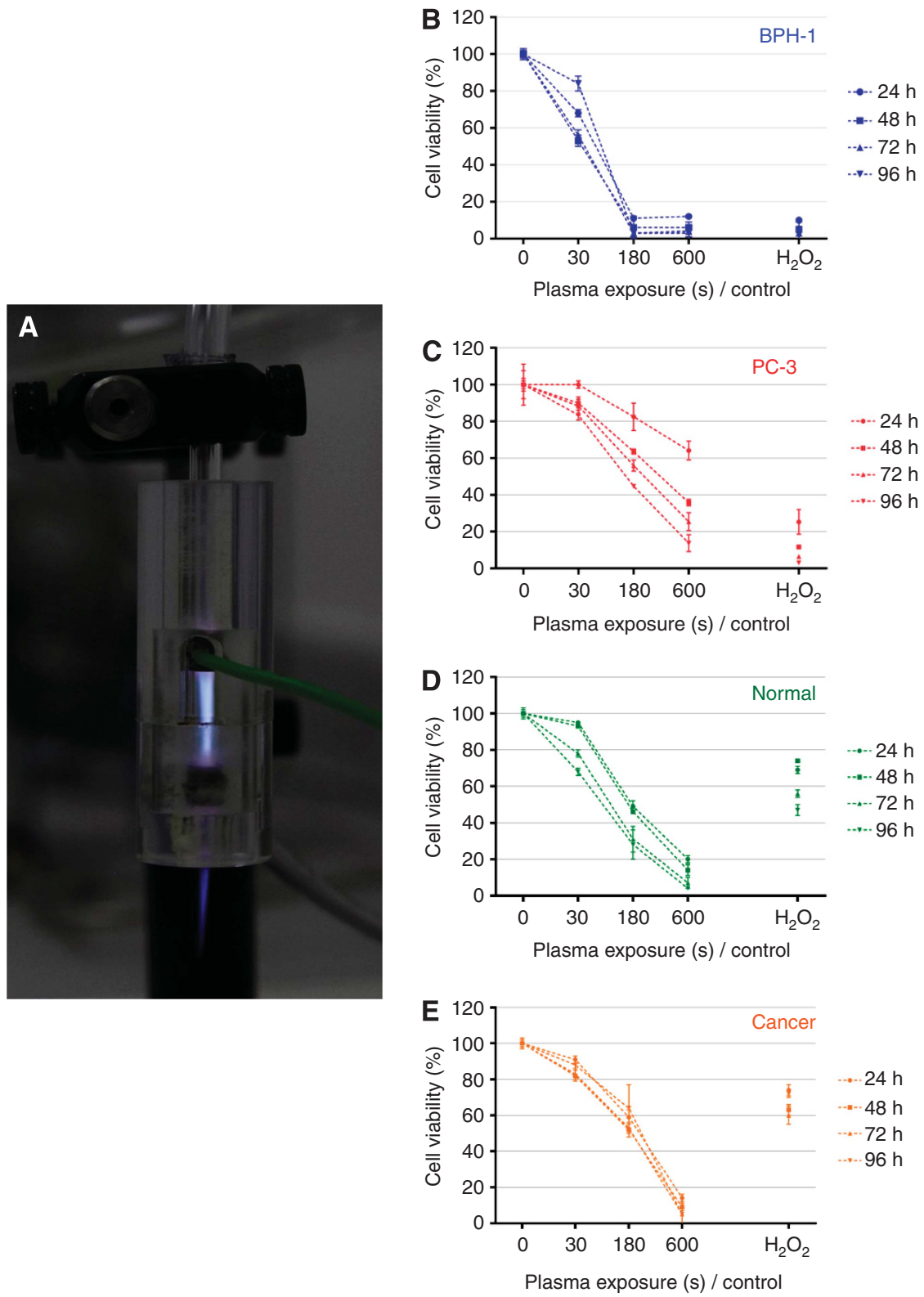

Figure 1. LTP treatment leads to a reduction in cell viability. (A) Cells were treated with a dielectric barrier discharge LTP jet, using 2 SLM helium flow rate with $0.3 \% \mathrm{O}_{2}$ admixture, operated at $6 \mathrm{kV}$ and $30 \mathrm{kHz}$. Reduction in cell viability was determined by alamarBlue assay (B, C) in BPH-1 and PC-3 cells and (D, E) in normal and cancer primary epithelial cells at $24,48,72$ and $96 \mathrm{~h}$ postexposure.

precoated with high melting point agarose and placed into lysis buffer $(2.5 \mathrm{M} \mathrm{NaCl}, 10 \mathrm{~mm}$ Tris, $1 \mathrm{~mm}$ EDTA, $10 \%$ DMSO, $1 \%$ Triton X-100), overnight at $4{ }^{\circ} \mathrm{C}$. The following day, cells were placed in alkaline buffer $(0.3 \mathrm{M} \mathrm{NaOH}, 1 \mathrm{~mm}$ EDTA, pH 13) on ice for $40 \mathrm{~min}$, before being electrophoresed at $23-25 \mathrm{~V}, 300 \mathrm{~mA}$ in alkaline buffer for a further $40 \mathrm{~min}$ on ice. Slides were then placed into neutralising buffer $(0.4 \mathrm{M}$ Tris, $\mathrm{pH} 7.5)$ for $2 \times 10 \mathrm{~min}$, before DNA was stained using SYBRgold (1:10000 in TE buffer: $10 \mathrm{~mm}$ Tris, 1 mm EDTA, pH 7.5). Images were acquired by fluorescence microscopy (Nikon Eclipse TE300 microscope (Nikon, Surrey, UK), $\times 10$ objective lens) using Volocity software (Volocity 6.3, PerkinElmer Inc., Waltham, MA, USA). Autocomet software (Tritek Corp., Sumerduck, VA, USA) was used to analyse cell images, with the median percentage of DNA-in-tail values used to record DNA damage in a minimum of 100 cells per treatment.

Detection of ROS. Extracellular $\mathrm{H}_{2} \mathrm{O}_{2}$ formed in the culture media as a result of LTP treatment was detected and quantified using the ROS-Glo $\mathrm{H}_{2} \mathrm{O}_{2}$ assay (Cat. no. G8820, Promega, Southhampton, UK). Cells were treated with LTP, before being plated into black-walled 96-well plates at a density of 10000 cells in $80 \mu \mathrm{l}$ of culture media, before following the manufacturer's protocol. Luminescence intensity was quantified using a microplate reader (Polarstar Optima, BMG Labtech) and normalised to untreated wells.

Western blotting. Cells were collected at 2, 4, 8, and $24 \mathrm{~h}$ following LTP treatment, and protein lysates were extracted using Cytobuster Protein Extraction Reagent (71009, EMD Millipore, Darmstadt, Germany) with protease inhibitors (cOmplete, EDTAfree Protease Inhibitor Cocktail Tablets, Roche Applied Science, Burgess Hill, West Sussex, UK). Primary antibodies included: cleaved-PARP (Asp214, 1:666, Cell Signalling Technology Inc., Hitchin, UK; no. 9541S), anti-LC3B (Ab51520, Abcam, Cambridge, UK; $1: 3000$ ), and monoclonal anti- $\beta$-actin $1: 5000$ (A5316, SigmaAldrich, Gillingham, UK; mouse). Secondary antibodies used 
included: anti-rabbit IgG HRP-linked (1:5000, Cell Signalling Technology Inc. no. 7074S), and anti-mouse IgG peroxidase ( $1: 5000$, Sigma-Aldrich A5906). Staurosporine $(1 \mu \mathrm{M})$ was used as a positive control for apoptosis (Cell Signalling Technology Inc. no. 9953). Kaleidoscope protein ladder was used as a marker for all gels (161-0375, Bio-Rad). Staurosporine $(1 \mu \mathrm{M})$ was used as a positive control for apoptosis (Cell Signalling Technology Inc. no. 9953). The ratio of LC3BII/I band intensity was performed using ImageJ software (Mount Royal, QC, Canada), with all bands quantified against $\beta$-actin loading control lanes and normalised untreated controls.

Caspase-Glo 3/7 assay. Cells were treated with LTP and plated into collagen-coated 96-well plates at a density of 20000 cells per well in $100 \mu \mathrm{l}$. A further $100 \mu \mathrm{l}$ of caspase-glo 3/7 detection reagent (Cat. no. G8090, Promega) was immediately added to each well. Cells were incubated at $37^{\circ} \mathrm{C}$, with luminescence intensity (Polarstar Optima, BMG Labtech) recorded at $24 \mathrm{~h}$ after treatment. Based on findings from other results, a reduced set of LTP exposures was used for this assay.

CellTox necrosis assay. LTP-induced necrosis was quantified using the CellTox green cytoxicity assay (Cat. no. G8741, Promega). Cells were treated with LTP and plated into collagencoated black-walled 96-well plates at a density of 10000 cells in $50 \mu \mathrm{l}$ of media per well. In addition to $\mathrm{H}_{2} \mathrm{O}_{2}$ and staurosporine, $2 \mu \mathrm{l}$ of lysis solution (supplied with assay) was added to necrotic control wells. Fluorescence intensity was recorded using a plate reader (Polarstar Optima, BMG Labtech), at excitation/emission wavelength $485 / 520 \mathrm{~nm}$, with readings at $2,4,8,12$, and $24 \mathrm{~h}$ after treatment. Fluorescence was normalised to untreated wells. Complementary fluorescence-brightfield merged microscopy images were also taken (Nikon Eclipse TE300 microscope, $\times 10$ objective lens) at the same posttreatment time intervals.

Statistical analysis. All experiments were performed in triplicate, and results are expressed as the mean with associated s.e., with the exception of comet assay data, which shows the median DNA damage value. Plots were constructed and statistical analyses performed using Prism 6 (GraphPad software, San Diego, CA, USA). Statistical significance was determined using unpaired Mann-Whitney test (DNA damage results only) or unpaired $t$-test with Welch's correction (assumes non-equal s.d.) and displayed on figure plots as ${ }^{\star} P<0.05,{ }^{* *} P<0.01,{ }^{* *} P<0.001$, and ${ }^{* * * *} P<0.0001$.

\section{RESULTS}

Reduction in cell viability is observed following LTP treatment. The viability of cells was quantified at $24,48,72$, and $96 \mathrm{~h}$ following LTP treatment (Figure 1). A reduction in viability in both BPH-1 (Figure 1B) and PC-3 (Figure 1C) cell lines was observed. BPH-1 viability was reduced to $<20 \%$, whereas viability of PC-3 cells was reduced to $<40 \%$. In addition, reduced cell viability was recorded in both normal and primary cells (Figure 1D and E), with 30-s LTP exposure leading to a small decrease in viability and 600-s exposure reducing cell viability to $<20 \%$. The positive $\mathrm{H}_{2} \mathrm{O}_{2}$ control was less toxic to both primary samples than the longer LTP exposures (180 and $600 \mathrm{~s}$ ). The cell lines were more susceptible to $1 \mathrm{mM} \mathrm{H}_{2} \mathrm{O}_{2}$, (up to $90 \%$ reduction) than primary cells, which only had a $\sim 30 \%$ reduction with $\mathrm{H}_{2} \mathrm{O}_{2}$ alone. Furthermore, the duration posttreatment had little effect on viability in primary samples, with comparable results recorded at 24 and $96 \mathrm{~h}$, particularly in the tumour cells (Figure 1E).

DNA damage is sustained as a result of LTP exposure. LTPinduced DNA damage was assessed using the alkaline comet assay, with the percentage of DNA-in-tail recorded for analysis.
Figure $2 \mathrm{~A}$ and $\mathrm{B}$ show the percentage of DNA damage in both $\mathrm{BPH}-1$ and PC-3 cells, respectively, for various exposure times. Each dot represents the DNA-in-tail percentage value from a single cell. Exposures as short as $30 \mathrm{~s}$ induced high levels of DNA damage, with a saturation of damage levels occurring from $180 \mathrm{~s}$. This concurs with findings in normal and tumour primary cells (Figure 2C and D). The level of DNA damage from LTP exposure was found to be consistently comparable to the $\mathrm{H}_{2} \mathrm{O}_{2}$ treatment control, and the level of damage in the tumour-derived primary sample (Figure 2D) was marginally higher (but statistically significant, $P<0.001)$ than that recorded for the normal sample (Figure 2C).

Inhibition of colony-forming capacity as a result of LTP treatment. Treatment with LTP showed a dose dependent inhibition of cell recovery in both BPH-1 and PC-3 cells, with the cancer cell line being more resistant than the benign cell line (Figure $3 \mathrm{~A}$ and B). Findings in primary cells showed that treatment with 600 -s LTP reduced the surviving fraction to $\sim 20 \%$ in both normal and tumour samples (Figure $3 \mathrm{E}$ and F). The tumour cells appeared significantly more resistant to the shorter 180-s LTP exposure and to the $\mathrm{H}_{2} \mathrm{O}_{2}$ control than the normal cells.

Evaluation of $\mathrm{H}_{2} \mathrm{O}_{2}$ formation in cell culture media. Cells in suspension were treated with LTP for a variety of times before being analysed for the presence of extracellular $\mathrm{H}_{2} \mathrm{O}_{2}$ in the cell culture media, as an indication of LTP-induced ROS production. It is well known that $\mathrm{H}_{2} \mathrm{O}_{2}$ is extremely toxic to cells (Bandyopadhyay et al, 1999), even at micromolar concentrations (Gulden et al, 2010). Figure 3C and D show an increase in the relative concentrations of $\mathrm{H}_{2} \mathrm{O}_{2}$ generated in the culture media with increasing LTP exposure times for BPH-1 and PC-3 cells. $\mathrm{H}_{2} \mathrm{O}_{2}$ production in PC-3 cells was far lower following LTP compared with $\mathrm{H}_{2} \mathrm{O}_{2}$ control, yet 180 and 600-s LTP exposures in BPH-1 cells were comparable to $\mathrm{H}_{2} \mathrm{O}_{2}$ control. In primary samples, a treatment time of $180 \mathrm{~s}$ yielded luminescence values comparable
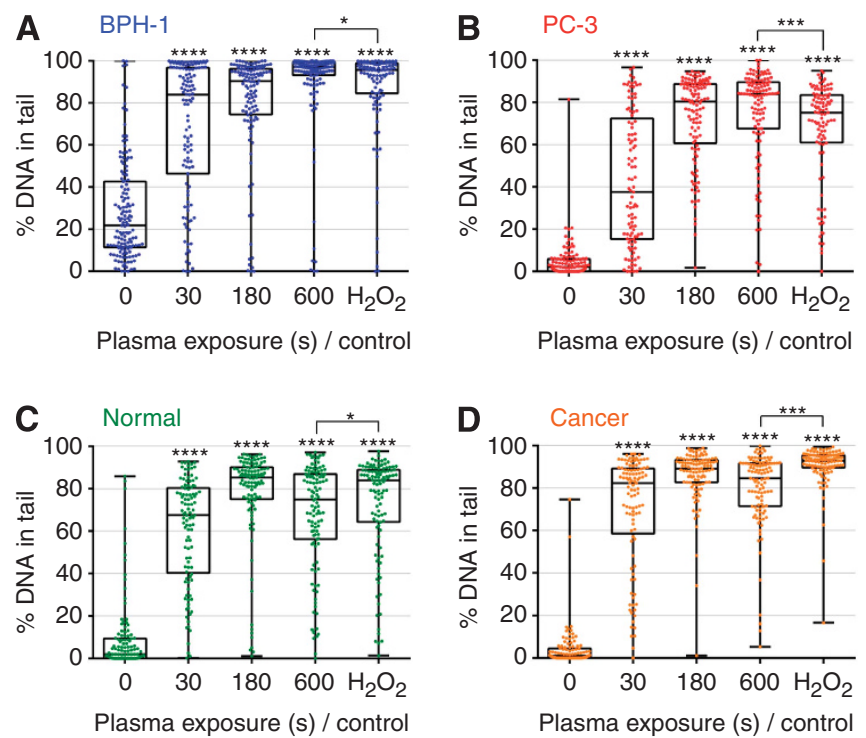

Figure 2. LTP treatment induces high levels of DNA damage in both prostate cell lines and primary epithelial cells. Cells were treated with LTP or $\mathrm{H}_{2} \mathrm{O}_{2}$ control (1 mM). DNA damage levels were measured using the alkaline comet assay and are represented as the percentage of DNA-in-tail in (A) BPH-1 and (B) PC-3 cells and in (C) normal and (D) cancer primary epithelial cells. Each dot represents a single cell, with a minimum of 100 cells counted for each exposure. Data are expressed as median \pm s.e. and are analysed by Mann-Whitney test. All significance was determined against untreated samples unless otherwise indicated. 
A
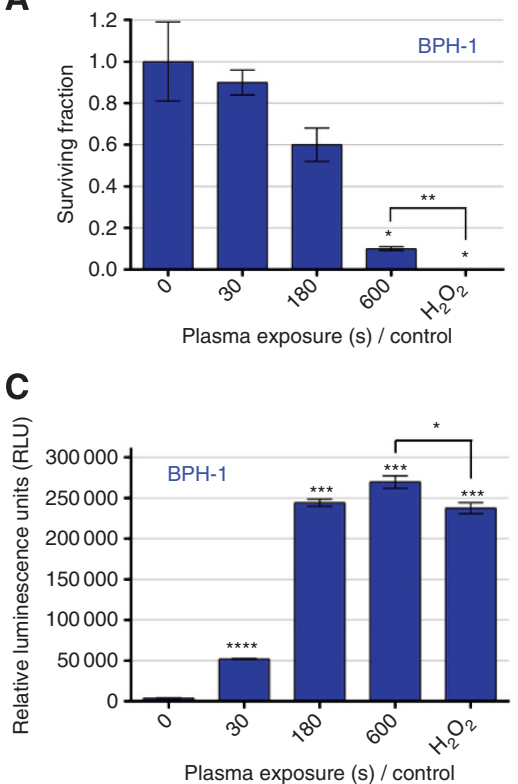

E

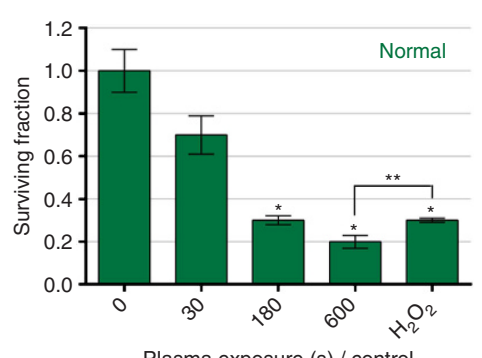

G

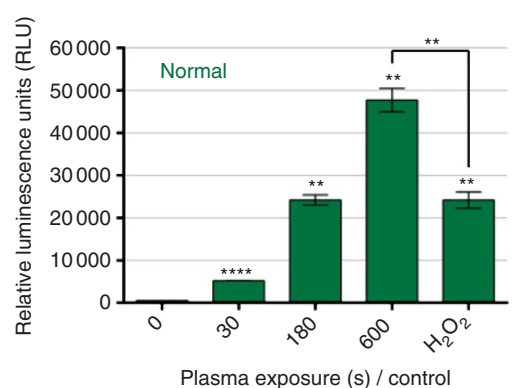

B

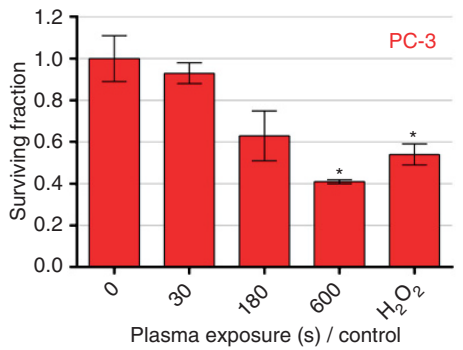

D

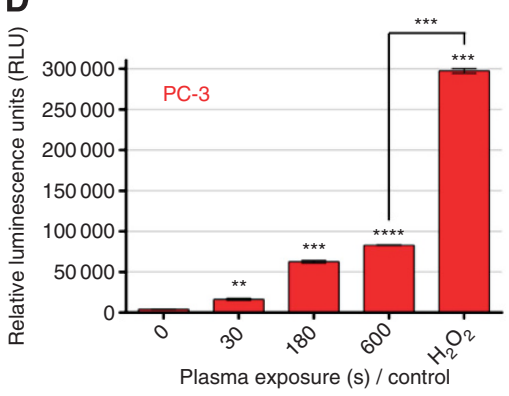

$\mathbf{F}$

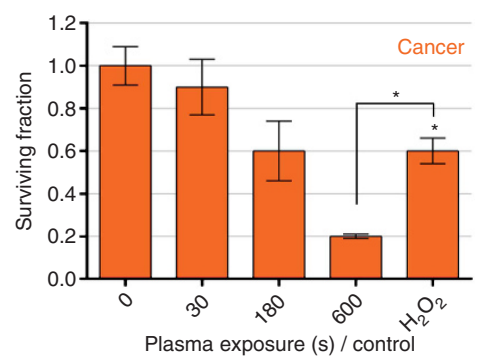

H

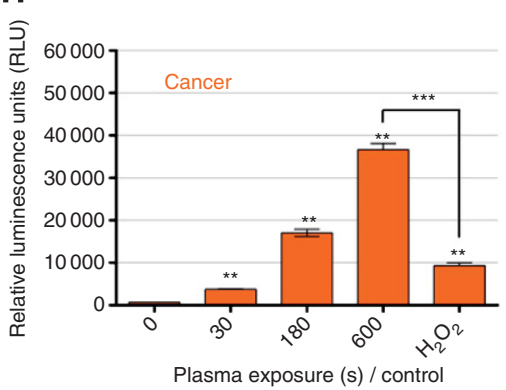

Figure 3. LTP treatment leads to reduction in colony-forming efficiency, and high levels of $\mathrm{H}_{2} \mathrm{O}_{2}$ in cell culture media. Cells were treated with LTP or $\mathrm{H}_{2} \mathrm{O}_{2}$ control $(1 \mathrm{~mm}$ ). Cell recovery was quantified using the colony-forming assays and is represented as surviving fraction posttreatment in (A) BPH-1 and (B) PC-3 cells and in (E) normal and (F) cancer primary epithelial cells. Immediately following treatment, $\mathrm{ROS}^{-} \mathrm{Glo} \mathrm{H}_{2} \mathrm{O}_{2}$ luminescence assay (Promega) was performed to ascertain $\mathrm{H}_{2} \mathrm{O}_{2}$ levels in the culture media of (C) BPH-1 and (D) PC-3 cells and in (G) normal and (H) cancer primary epithelial cells (Note the different $y$ axis scales). Data are expressed as mean \pm s.e., with statistical analysis conducted using unpaired $t$-test with Welch's correction. All significance was determined against untreated samples unless otherwise indicated.

to $1 \mathrm{mM} \mathrm{H}_{2} \mathrm{O}_{2}$ positive control in normal cells. An exposure time of $600 \mathrm{~s}$ corresponded to approximately two-fold of the concentration of a $1 \mathrm{~mm} \mathrm{H}_{2} \mathrm{O}_{2}$ positive control in normal cells and three-fold in cancer cells (Figure $3 \mathrm{G}$ and $\mathrm{H}$ ).

LTP exposure induces different cell death pathways in cells lines and primary prostate epithelial cells. Our results indicate that LTP exposure causes necrosis in both BPH-1 and PC-3 cell lines, as seen in Figure 4A and B. It is clear that PC-3 cells are more resistant to LTP-induced necrosis than BPH-1 cells. Significantly, necrotic cell death was also observed in both normal and cancer prostate primary cells. Figure $4 \mathrm{C}$ and D indicate that 180 - and 600-s LTP exposures lead to high levels of necrosis compared with untreated control, with the findings common to both normal and cancer samples. This was verified by supportive fluorescence images taken at $4 \mathrm{~h}$ after treatment, which highlighted cells positive for necrosis (green) in 180- and 600-s LTP exposure wells, whereas staurosporine controls were largely negative at this time point.

Initially, the levels of necrosis at $2 \mathrm{~h}$ posttreatment were comparable for 180- and 600-s exposures. Cells treated with 600-s LTP showed a marked time-dependent increase in necrosis, whereas values for 180 -s samples remained approximately constant. Interestingly, cytopathic effects with the pure $\mathrm{H}_{2} \mathrm{O}_{2}$ 
A

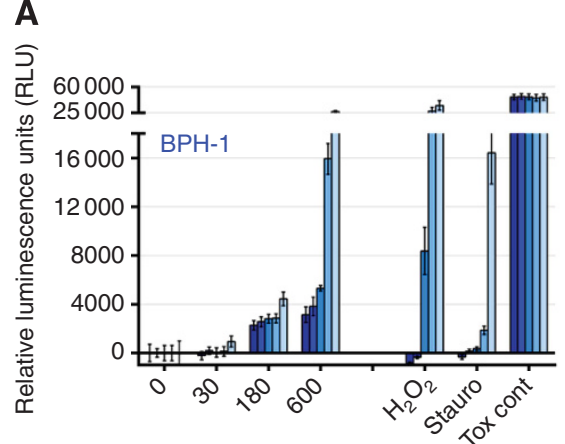

Plasma exposure (s) / control

\section{B}

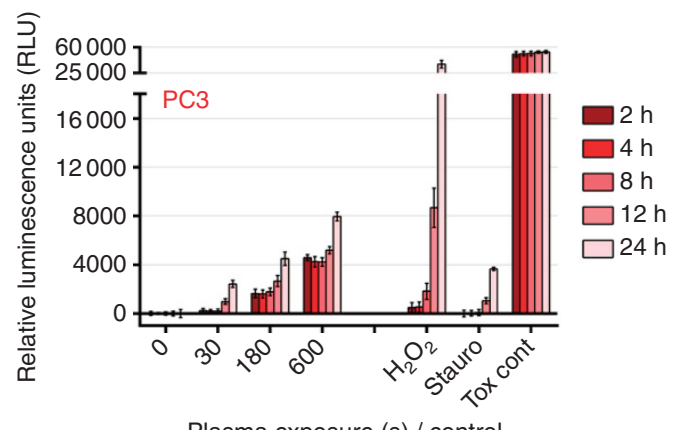

Plasma exposure (s) / control

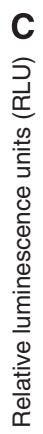

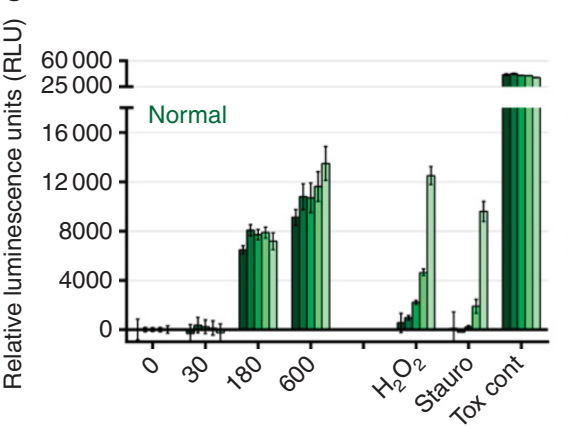

Plasma exposure (s) / control

D

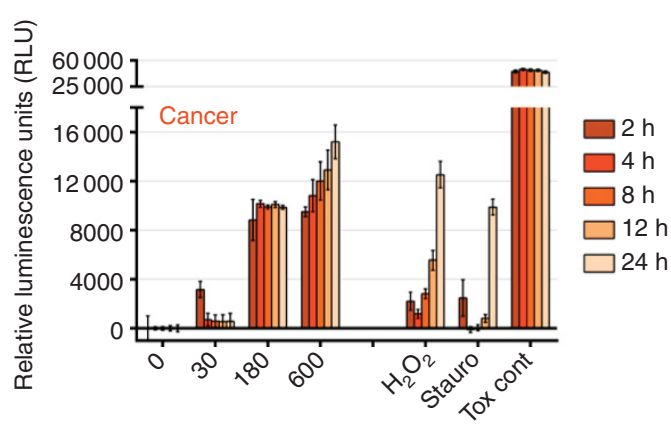

Plasma exposure (s) / control
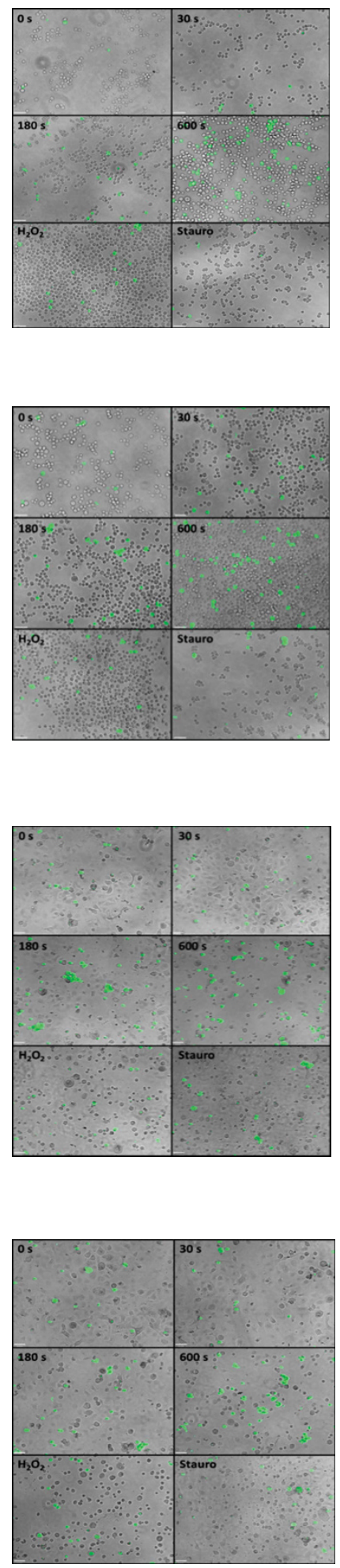

Figure 4. LTP treatment leads to necrotic cell death in both prostate cell lines and primary epithelial cells. Immediately following LTP treatment, the CellTox green cytoxicity assay (Promega) was performed to identify cells with comprimised membrane integrity characteristic of necrosis. In all, $1 \mathrm{mM} \mathrm{H}_{2} \mathrm{O}_{2}, 1 \mu \mathrm{M}$ staurosporine, and cell lysing agent (supplied with assay) were used as controls. Fluorescence intensity was quantified at 2, 4, 8, 12 , and $24 \mathrm{~h}$ following treatment and normalised to untreated control wells in (A) BPH-1 and (B) PC-3 cell lines and in (C) normal and (D) cancer primary epithelial cells. Data are expressed as mean \pm s.e. Supporting fluorescence microscopy images $(\times 10$ magnification) taken at $4 \mathrm{~h}$ after treatment are also shown for each cell type. 
control did not present until around $12-24 \mathrm{~h}$ after treatment. Likewise, the staurosporine treatment induced necrosis only at $24 \mathrm{~h}$, indicative of late-stage apoptosis.

In addition to necrosis, a proportion of $\mathrm{BPH}-1$ cells also underwent apoptosis following LTP exposure as verified by western blotting for the presence of cleaved-PARP, whereas PC-3 cells did not (Figure 5A and B). Primary cells treated with LTP did not undergo apoptosis (Figure 5C and D). This was further confirmed by assessment of caspase 3 and 7 activity in primary samples (Caspase-glo 3/7 assay, Promega), where only staurosporine-treated positive control cells showed positive expression (Figure 5E). Indeed, LTP-treated primary cells showed apoptotic activity levels below those of untreated control, further verifying

A

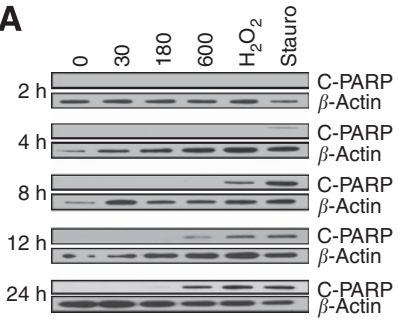

C
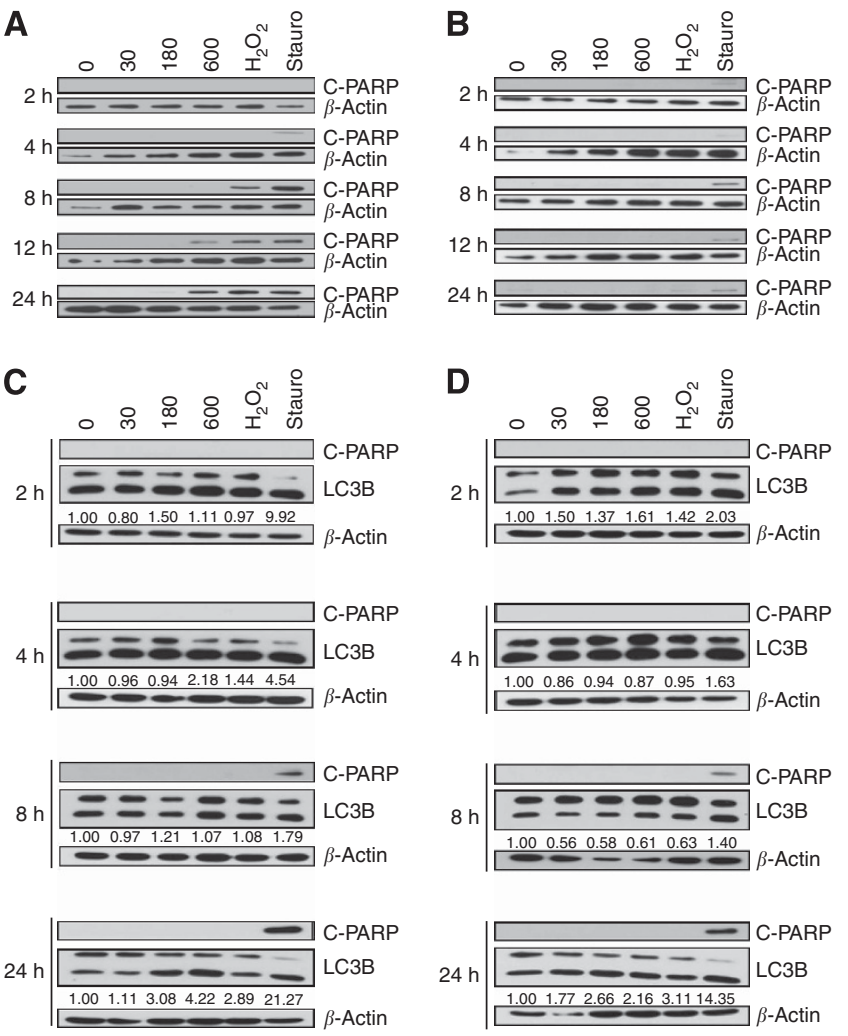

D
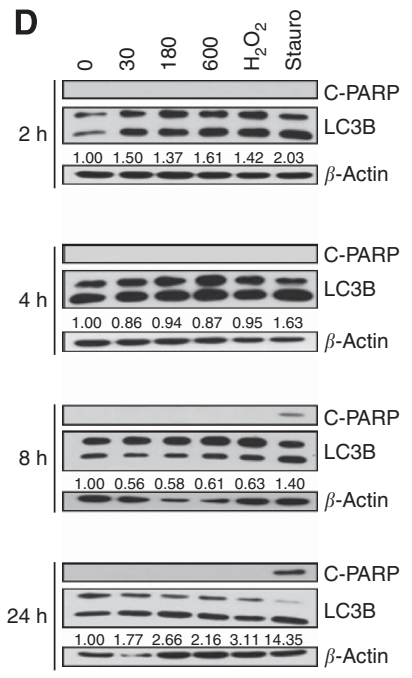

E

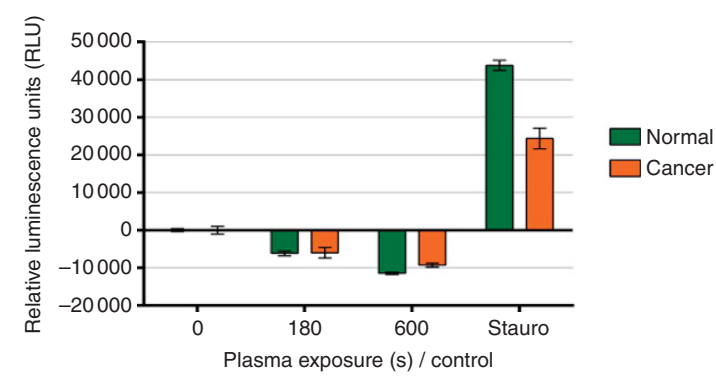

Figure 5. Cell death mechanisms following LTP treatment vary between cell types. Following treatment with LTP, $1 \mathrm{mM} \mathrm{H}_{2} \mathrm{O}_{2}$, or $1 \mu \mathrm{M}$ staurosporine, protein lysates were harvested. (A) BPH-1 and (B) PC-3 cell line lysates were probed for apoptosis (C-PARP) by western blotting. (C) Normal and (D) cancer primary epithelial lysates were probed for apoptosis (C-PARP) and also autophagy (LC3B I/II). $\beta$-Actin was used as a loading control throughout. Band intensity quantification was performed using the ImageJ software. Further analysis of apoptotic activity was conducted in (E) primary epithelial cells using Caspase-glo $3 / 7$ assay (Promega). Immediately following treatment, caspase-glo 3/7 detection reagent was added to all wells, and luminescence intensity was quantified at $24 \mathrm{~h}$. Readings were normalised to untreated control and are expressed as mean \pm s.e. that cell death following LTP exposure occurs through necrosis and not apoptosis.

In addition to apoptosis and necrosis, another cellular response to stress is autophagy, which can serve as a protective mechanism, but also results in cell death. Quantitation of LC3 II/I band intensity revealed that, by $24 \mathrm{~h}$ posttreatment, a more than twoand a more than four-fold increase (over untreated controls) was present in the cancer and normal samples, respectively, indicating that an autophagic response occurred following LTP exposure (Figure 5C and D).

\section{DISCUSSION}

In this work, we have shown that treatment with LTP causes DNA damage, a reduction in both cell viability and recovery, and ultimately necrotic cell death in normal and cancer primary prostate epithelial cells. The results indicate that LTP-induced $\mathrm{H}_{2} \mathrm{O}_{2}$ in the culture media is a likely facilitator of these effects. We also observed that, unlike primary cells and the PC-3 cell line, BPH-1 cells also die through apoptotic mechanisms following plasma treatment (Figure 6). Our findings in primary cells highlight the potential of LTP as an alternative to, or for use in conjunction with, other existing treatments for organ-confined prostate cancer. Furthermore, the differential cell death response between cell lines and primary cells stresses the need to study clinically relevant models in order to gain insight into the potential patient response.

LTP exposure is known to cause cytotoxic effects in cells via the delivery of RONS to the liquid environment (Ahn et al, 2014; Ishaq

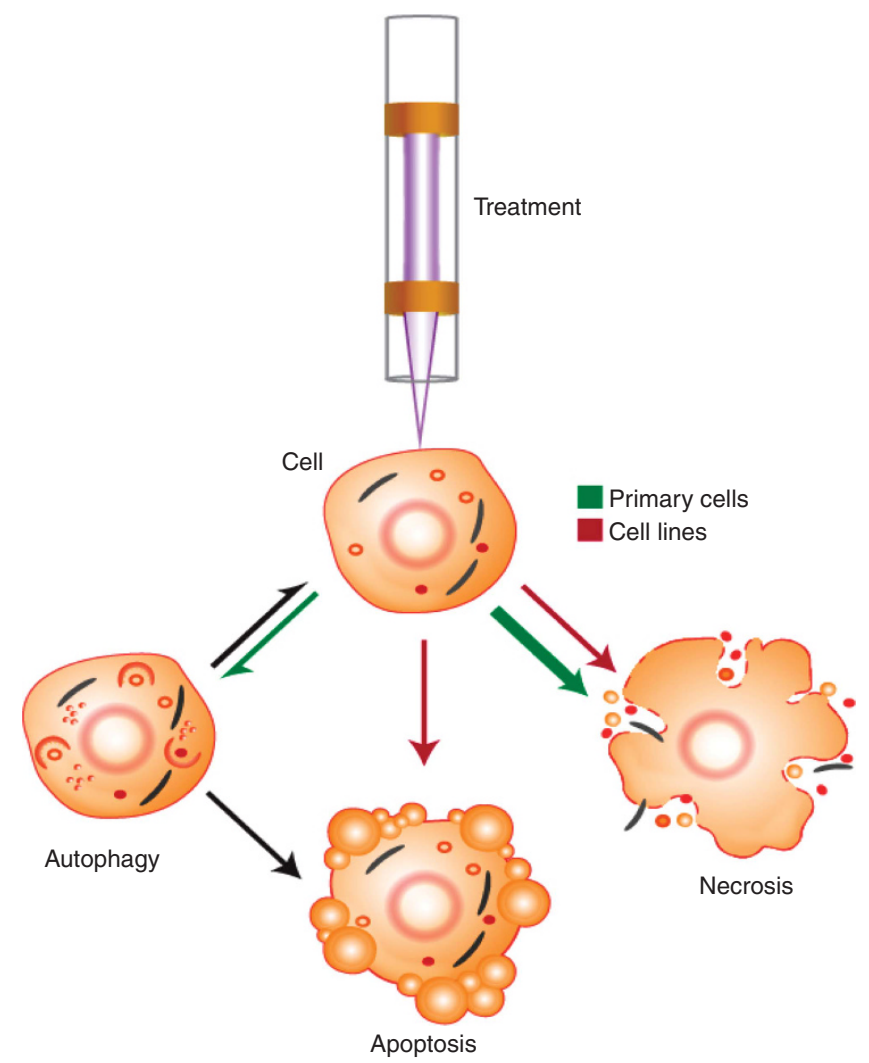

Figure 6. Overview of cellular response mechanism following LTP treatment. As a result of exposure to LTP, cells were observed to undergo (or a combination of) autophagy, apoptosis or necrosis. The relative proportions of, and differences between, cell lines (red arrows) and primary epithelial cells (green arrows) that exhibit these phenomena is emphasised. Adapted from Kepp et al (2011). 
et al, 2014; Ma et al, 2014). Our results indicate that 180-s LTP treatment of prostate primary cells leads to $\mathrm{H}_{2} \mathrm{O}_{2}$ concentrations approximately equal to that of a $1 \mathrm{mM} \mathrm{H}_{2} \mathrm{O}_{2}$ control. Additionally, LTP exposure of $600 \mathrm{~s}$ produced statistically significant $\mathrm{H}_{2} \mathrm{O}_{2}$ readings two- to three-fold to those of the control. Interestingly, following exposure to LTP, the levels of $\mathrm{H}_{2} \mathrm{O}_{2}$ recorded in the tumour cells were found to be lower generally than those from the normal cells, resulting in an enhanced colony recovery following treatment at 30- and 180-s LTP treatment times but not at the longest exposure of $600 \mathrm{~s}$. This is in keeping with recent data, suggesting that cancer cells have the ability to quench the effects of ROS more effectively than normal cells (Diehn et al, 2009; Gorrini et al, 2013). Despite this, cell viability is still strongly reduced following LTP treatments of 180 and $600 \mathrm{~s}$, indicating that any RONS produced initially in the culture medium remain strongly damaging to the primary cells at increased time periods postexposure. In contrast to data from the proof-of-principle study on prostate cell lines (Figure $1 \mathrm{~B}$ and $\mathrm{C}$ ), the primary samples appear far more resistant to the $\mathrm{H}_{2} \mathrm{O}_{2}$ control, yet the reduction in viability as a result of LTP exposure is comparable between the different samples (Figure $2 \mathrm{C}$ and $\mathrm{D}$ ). This suggests that the enhanced effect of the plasma is likely to be due to a cumulative effect on the cells of a multitude of reactive species produced in the plasma (the presence of atomic oxygen in the plasma core was verified by optical emission spectroscopy, Supplementary Figure S1), and/or additional plasma components such as electric fields, charges, and UV radiation (Graves, 2012; Kang et al, 2014), rather than just solely due to $\mathrm{H}_{2} \mathrm{O}_{2}$. This may also make it unlikely for cancer cells to become resistant to treatment, as increased tolerance to a particular reactive species would not protect against the perceived multi-faceted action of LTP. Because of the added presence of reactive nitrogen species produced by some LTPs (Cheng et al, 2014; Gibson et al, 2014), this may also present an advantage over radiotherapy, which relies heavily on ROS alone (Palacios et al, 2013), and over PDT, which relies predominantly on the single reactive species SDO for its cytotoxic effect (Sharman et al, 1999).

A contribution of the cell culture media to the observed effects cannot be discounted. We measured a three-fold increase over control of $\mathrm{H}_{2} \mathrm{O}_{2}$ production after plasma treatment in primary cells. Yet, we see that, in the BPH-1 cell line, the LTP-treated $\mathrm{H}_{2} \mathrm{O}_{2}$ concentrations are broadly similar, and in the PC-3 cell line the $\mathrm{H}_{2} \mathrm{O}_{2}$ concentrations are much lower than the control (Figure $1 \mathrm{E}$ and $\mathrm{F}$ ). It is known that different cell culture media can produce different amounts of $\mathrm{H}_{2} \mathrm{O}_{2}$ (Promega Technical Services, private communication). We therefore considered treating all cell types in a buffered saline solution and re-plating the cells in their optimal culture media. However, a counter-argument is that this would not have been physiological (with respect to treating a patient) and that any cytopathic effect would be likely to be predominantly due to short-lived reactive species, and the prolonged effects of long-lived species would be lost. Significantly, both normal and cancer primary cells used in this study were cultured and treated in identical media without serum, and so media was not a variable factor and the results from these cells can be directly compared.

Differences in $\mathrm{H}_{2} \mathrm{O}_{2}$ levels were recorded in treated media containing cells and treated media only. All plasma-treated samples showed a reduction in $\mathrm{H}_{2} \mathrm{O}_{2}$ production in the presence of cells ( $v s$ treated media), suggesting that the cells consume, or quench, $\mathrm{H}_{2} \mathrm{O}_{2}$ in the media (Supplementary Figure S2A). This was by far the most pronounced in primary cells, where the $\mathrm{H}_{2} \mathrm{O}_{2}$ level following 180-s LTP exposure was reduced by $78 \%$ in the presence of cells. There was far less of a reduction in BPH-1 cells (17\%) and PC-3 cells (41\%). It was also found that, by $2 \mathrm{~h}$ following treatment, the levels of $\mathrm{H}_{2} \mathrm{O}_{2}$ (induced by either 600-s plasma treatment or $1 \mathrm{mM} \mathrm{H}_{2} \mathrm{O}_{2}$ ) were strongly reduced in both normal and tumour primary cells. This effect was more pronounced in the tumour cells and demonstrates the strong ROS-quenching capacity of the primary cells (Supplementary Figure S2B and C). The level of $\mathrm{H}_{2} \mathrm{O}_{2}$ formed by the positive control was further reduced to that of the untreated cells by $8 \mathrm{~h}$; however, there were still elevated levels of $\mathrm{H}_{2} \mathrm{O}_{2}$ induced by plasma treatment detected at this time point.

We have found that high levels of DNA damage, which is uniform across all cell types, is inflicted after an LTP exposure of only $30 \mathrm{~s}$. In addition, a reduction in colony-forming ability following LTP treatment was observed, as cells treated with 600-s LTP recovered significantly less than those treated with the $\mathrm{H}_{2} \mathrm{O}_{2}$ control. This is despite the DNA damage values between $600 \mathrm{~s}$ and $\mathrm{H}_{2} \mathrm{O}_{2}$ control differing by only a few percent across all samples, in support of the hypothesis that the cytocidal effect of the plasma on cells is not solely due to $\mathrm{H}_{2} \mathrm{O}_{2}$ production. Therefore, in vitro, retaining the cells in treated media is necessary to realise a strong anti-proliferative effect (which we investigated and found to be the case; data not shown), as would be seen in tissues. Other LTPbased studies report a selective plasma effect (Wang et al, 2013; Guerrero-Preston et al, 2014), that is, that the plasma preferentially induces cell death in cancer cells. However, normal and tumour cell lines studied often originate from different sites or hosts or are cultured in different media. We observe similar responses in both primary prostate tumour and normal cells from the same patient, highlighting the necessity for supporting live imaging, for example, MRI, for precise targeted tumour ablation in patients (Sullivan and Crawford, 2009).

Finally, for any progression towards a patient therapy, further elucidation of the mechanism of LTP-induced cell death is required. Following a fatal stimulus, cell death can occur broadly in one of the two ways; apoptosis - a regulated chain of events involving cell shrinkage, blebbing, and ending with the formation of apoptotic bodies that retain membrane integrity (Cohen, 1997), or necrosis - an uncontrolled swelling that leads to membrane rupture and spillage of the cell contents into the surrounding environment, provoking an inflammatory response (Casiano et al, 1998). It is clear from our results that primary cells rapidly undergo necrosis, in the almost complete absence of apoptosis. A major advantage of this is that necrotic cell death has the potential to promote immune-activation against tumour cells (Melcher et al, 1999). In contrast, apoptotic cell death has been observed to promote an immune-suppressive environment (Voll et al, 1997), allowing tumour cells to evade detection by the immune system (Gregory and Pound, 2010). Our findings were common to both normal and cancer primary sample with some subtle differences. Marginally higher levels of necrosis were observed in the cancer cells following 600-s exposure, yet both samples show almost identical recovery from this treatment (20\% surviving fraction). Both normal and cancer cells treated with long LTP exposures (180 and 600 s) undergo autophagy: a completely novel finding in LTP studies on human cells. This may be a survival process for cells that do not undergo necrosis. Our observation of higher levels of autophagy in primary normal cells may be attributed to the hypothesis that normal cells have a higher ROS-threshold tolerance than cancer cells (Gorrini et al, 2013).

Although this study argues that LTP could become a potential focal therapy for localised $\mathrm{PCa}$, it remains possible that a reduction in metastatic tumour volume could be observed after treatment with LTP, as a result of necrotic cell death and its associated immune response as outlined earlier. Referred to as spontaneous regression, this response has been documented following necrosisinducing thermal ablation treatments for other cancers (SanchezOrtiz et al, 2003; Kim et al, 2008; Chu and Dupuy, 2014), but the mechanisms responsible are largely unknown. Nevertheless, a proportion of cells survive LTP treatment and are able to proliferate following exposure to LTP, as demonstrated by their residual colony-forming capacity. The reasons for this must be determined and may potentially be overcome by manipulation and 
optimisation of the plasma parameters (Cheng et al, 2014) and/or pretreatment with a sensitising agent (Frame et al, 2013).

Finally, the differences in response we have observed between prostate cell lines and primary cells, particularly in terms of the mechanism of cell death, highlights the importance of studying primary cultures in order to gain an insight into patient efficacy. More specifically, the cell death mechanisms that are triggered following administration of LTP should be elucidated in close-topatient models.

\section{CONCLUSIONS}

In summary, we have clearly demonstrated the potential of LTP as a future therapy option for localised prostate cancer. Through the formation of reactive species $\left(\mathrm{H}_{2} \mathrm{O}_{2}\right.$ and more than likely also others, e.g., $\mathrm{OH}, \mathrm{O}_{2}^{-}$) in cell culture media, we observed high levels of DNA damage in primary cells cultured directly from patient tissues, together with reduction in cell viability and colony-forming ability. These ultimately lead to necrotic cell death in both normal and tumour samples. However, further optimisation of the LTP operational parameters needs to be conducted, in order to kill the proportion of cells that remain viable after treatment. In addition, although we have previously outlined a potential approach (Hirst et al, 2014b), the feasibility of physically treating patients who have PCa with LTP has yet to be established. This would require some modification of the LTP device itself to deliver the LTP to the tumour bed, sparing normal tissues, perhaps employing existing apparatus for cryotherapy and/or brachytherapy.

We believe that with appropriate imaging techniques to facilitate accurate tumour targeting and spare normal tissues, the multifaceted action of LTP will provide advantages over other focal therapies. More specifically, therapies such as PDT relies on SDO production to destroy cells; plasmas are known to be able produce a multitude of RONS that are toxic to cells. Given that LTPs can be propagated from tubes $<100 \mu \mathrm{m}$ in diameter (Kim et al, 2011), we believe that LTP therapy could be more targeted than radiotherapy and more controlled than ice-ball formation in cryotherapy. LTP would not require additional equipment such as the warming catheters used in cryosurgery. Moreover, LTP treatment should prove far more cost-effective than existing treatments.

\section{ACKNOWLEDGEMENTS}

This work was part-funded by the Wellcome Trust: ref: 097829/Z/ 11/A and the UK EPSRC through a Career Acceleration Fellowship: EP/H003797/1 (O'Connell) and Manufacturing the Future grant: $\mathrm{EP} / \mathrm{K} 018388 / 1$ (all to O'Connell). We acknowledge funding from Yorkshire Cancer Research: YCR - Y257PA (Frame, Maitland). We thank P Roberts (University of York, UK) for his assistance with the graphic design used in this paper, A West (University of York, UK) for his assistance with optical emission spectroscopy, and also all the patients and urology surgeons L Coombes, G Cooksey, and J Hetherington (Castle Hill Hospital, Cottingham, UK).

\section{REFERENCES}

Ahn HJ, Kim KI, Hoan NN, Kim CH, Moon E, Choi KS, Yang SS, Lee JS (2014) Targeting cancer cells with reactive oxygen and nitrogen species generated by atmospheric-pressure air plasma. PLoS One 9: e86173.

Bandyopadhyay U, Das D, Banerjee RK (1999) Reactive oxygen species: oxidative damage and pathogenesis. Curr Sci 77: 658-666.
Casiano CA, Ochs RL, Tan EM (1998) Distinct cleavage products of nuclear proteins in apoptosis and necrosis revealed by autoantibody probes. Cell Death Differ 5: 183-190.

Chang JW, Kang SU, Shin YS, Kim KI, Seo SJ, Yang SS, Lee JS, Moon E, Baek SJ, Lee K, Kim CH (2014) Non-thermal atmospheric pressure plasma induces apoptosis in oral cavity squamous cell carcinoma: Involvement of DNA-damage-triggering sub-G(1) arrest via the ATM/p53 pathway Arch Biochem Biophys 545: 133-140.

Chen MJ, Weltman E, Hanriot RM, Luz FP, Cecilio PJ, Da Cruz JC, Moreira FR, Santos AS, Martins LC, Nadalin W (2007) Intensity modulated radiotherapy for localized prostate cancer: rigid compliance to dose-volume constraints as a warranty of acceptable toxicity? Radiat Oncol 2: 6.

Cheng X, Sherman J, Murphy W, Ratovitski E, Canady J, Keidar M (2014) The effect of tuning cold plasma composition on glioblastoma cell viability. PLoS One 9: e98652.

Chu KF, Dupuy DE (2014) Thermal ablation of tumours: biological mechanisms and advances in therapy. Nat Rev Cancer 14: 199-208.

Cohen GM (1997) Caspases: the executioners of apoptosis. Biochem J 326(Pt 1): $1-16$.

Collins AT, Berry PA, Hyde C, Stower MJ, Maitland NJ (2005) Prospective identification of tumorigenic prostate cancer stem cells. Cancer Res 65: 10946-10951.

Diehn M, Cho RW, Lobo NA, Kalisky T, Dorie MJ, Kulp AN, Qian D, Lam JS, Ailles LE, Wong M, Joshua B, Kaplan MJ, Wapnir I, Dirbas FM, Somlo G, Garberoglio C, Paz B, Shen J, Lau SK, Quake SR, Brown JM, Weissman IL, Clarke MF (2009) Association of reactive oxygen species levels and radioresistance in cancer stem cells. Nature 458: 780-783.

Donaldson IA, Alonzi R, Barratt D, Barret E, Berge V, Bott S, Bottomley D, Eggener S, Ehdaie B, Emberton M, Hindley R, Leslie T, Miners A, Mccartan N, Moore CM, Pinto P, Polascik TJ, Simmons L, Van Der Meulen J, Villers A, Willis S, Ahmed HU (2014) Focal therapy: patients, interventions, and outcomes-a report from a consensus meeting. Eur Urol 67(4): 771-777.

Frame FM, Pellacani D, Collins AT, Simms MS, Mann VM, Jones GD, Meuth M, Bristow RG, Maitland NJ (2013) HDAC inhibitor confers radiosensitivity to prostate stem-like cells. Br J Cancer 109: 3023-3033.

Francipane MG, Alea MP, Lombardo Y, Todaro M, Medema JP, Stassi G (2008) Crucial role of interleukin-4 in the survival of colon cancer stem cells. Cancer Res 68: 4022-4025.

Gibson AR, Mccarthy HO, Ali AA, O'connell D, Graham WG (2014) Interactions of a non-thermal atmospheric pressure plasma effluent with PC-3 prostate cancer cells. Plasma Process Polym 11(12): 1142-1149.

Gorrini C, Harris IS, Mak TW (2013) Modulation of oxidative stress as an anticancer strategy. Nat Rev Drug Discov 12: 931-947.

Graves DB (2012) The emerging role of reactive oxygen and nitrogen species in redox biology and some implications for plasma applications to medicine and biology. J Phys D Appl Phys 45: 263001.

Graves DB (2014) Low temperature plasma biomedicine: a tutorial reviewa. Phys Plasmas 21: 080901.

Gregory CD, Pound JD (2010) Microenvironmental influences of apoptosis in vivo and in vitro. Apoptosis 15: 1029-1049.

Guerrero-Preston R, Ogawa T, Uemura M, Shumulinsky G, Valle BL, Pirini F, Ravi R, Sidransky D, Keidar M, Trink B (2014) Cold atmospheric plasma treatment selectively targets head and neck squamous cell carcinoma cells. Int J Mol Med 34: 941-946.

Gulden M, Jess A, Kammann J, Maser E, Seibert H (2010) Cytotoxic potency of $\mathrm{H}_{2} \mathrm{O} 2$ in cell cultures: impact of cell concentration and exposure time. Free Radic Biol Med 49: 1298-1305.

Hirst AM, Frame FM, Maitland NJ, O'connell D (2014a) Low temperature plasma causes double-strand break DNA damage in primary epithelial cells cultured from a human prostate tumor. Plasma Sci IEEE Trans 42(10): 2740-2741.

Hirst AM, Frame FM, Maitland NJ, O'connell D (2014b) Low temperature plasma: a novel focal therapy for localized prostate cancer? Biomed Res Int 2014: 878319.

Ishaq M, Kumar S, Varinli H, Han ZJ, Rider AE, Evans MD, Murphy AB, Ostrikov K (2014) Atmospheric gas plasma-induced ROS production activates TNF-ASK1 pathway for the induction of melanoma cancer cell apoptosis. Mol Biol Cell 25: 1523-1531.

Jemal A, Bray F, Center MM, Ferlay J, Ward E, Forman D (2011) Global cancer statistics. CA Cancer J Clin 61: 69-90. 
Jones JS (2011) Radiorecurrent prostate cancer: an emerging and largely mismanaged epidemic. Eur Urol 60: 411-412.

Kang SU, Cho JH, Chang JW, Shin YS, Kim KI, Park JK, Yang SS, Lee JS, Moon E, Lee K, Kim CH (2014) Nonthermal plasma induces head and neck cancer cell death: the potential involvement of mitogen-activated protein kinase-dependent mitochondrial reactive oxygen species. Cell Death Dis 5: e1056.

Kasivisvanathan V, Emberton M, Ahmed HU (2013) Focal therapy for prostate cancer: rationale and treatment opportunities. Clin Oncol (R Coll Radiol) 25: 461-473.

Keidar M, Walk R, Shashurin A, Srinivasan P, Sandler A, Dasgupta S, Ravi R, Guerrero-Preston R, Trink B (2011) Cold plasma selectivity and the possibility of a paradigm shift in cancer therapy. Br J Cancer 105: 1295-1301.

Kepp O, Galluzzi L, Lipinski M, Yuan J, Kroemer G (2011) Cell death assays for drug discovery. Nat Rev Drug Discov 10: 221-237.

Kim H, Park BK, Kim CK (2008) Spontaneous regression of pulmonary and adrenal metastases following percutaneous radiofrequency ablation of a recurrent renal cell carcinoma. Korean J Radiol 9: 470-472.

Kim JY, Ballato J, Foy P, Hawkins T, Wei Y, Li J, Kim SO (2011) Apoptosis of lung carcinoma cells induced by a flexible optical fiber-based cold microplasma. Biosens Bioelectron 28: 333-338.

Knake N, Niemi K, Reuter S, Schulz-Von Der Gathen V, Winter J (2008) Absolute atomic oxygen density profiles in the discharge core of a microscale atmospheric pressure plasma jet. Appl Phys Lett 93: 131503131503.

Krzykawska-Serda M, Dabrowski JM, Arnaut LG, Szczygiel M, Urbanska K, Stochel G, Elas M (2014) The role of strong hypoxia in tumors after treatment in the outcome of bacteriochlorin-based photodynamic therapy. Free Radic Biol Med 73C: 239-251.

Lips IM, Dehnad H, Van Gils CH, Boeken Kruger AE, Van Der Heide UA, Van Vulpen M (2008) High-dose intensity-modulated radiotherapy for prostate cancer using daily fiducial marker-based position verification: acute and late toxicity in 331 patients. Radiat Oncol 3: 15 .

Ma Y, Ha CS, Hwang SW, Lee HJ, Kim GC, Lee KW, Song K (2014) Nonthermal atmospheric pressure plasma preferentially induces apoptosis in p53-mutated cancer cells by activating ROS stress-response pathways. PLoS One 9: e91947.

Melcher A, Gough M, Todryk S, Vile R (1999) Apoptosis or necrosis for tumor immunotherapy: what's in a name? J Mol Med (Berl) 77: 824-833.

Murakami T, Niemi K, Gans T, O'connell D, Graham WG (2013) Chemical kinetics and reactive species in atmospheric pressure helium-oxygen plasmas with humid-air impurities. Plasma Sources Sci Technol 22: 015003.

Niemi K, O'connell D, Oliveira DE, Joyeux N, Nahon D, Booth L, Gans, T. JP (2013) Absolute atomic oxygen and nitrogen densities in radio-frequency driven atmospheric pressure cold plasmas: synchrotron vacuum ultraviolet high-resolution Fourier-transform absorption measurements. Appl Phys Lett 103: 034102.

Ninomiya K, Ishijima T, Imamura M, Yamahara T, Enomoto H, Takahashi K, Tanaka Y, Uesugi Y, Shimizu N (2013) Evaluation of extra- and intracellular $\mathrm{OH}$ radical generation, cancer cell injury, and apoptosis induced by a non-thermal atmospheric-pressure plasma jet. J Phys D Appl Phys 46: 425401.
Palacios DA, Miyake M, Rosser CJ (2013) Radiosensitization in prostate cancer: mechanisms and targets. BMC Urol 13: 4.

Plewa JM, Yousfi M, Frongia C, Eichwald O, Ducommun B, Merbahi N, Lobjois V (2014) Low-temperature plasma-induced antiproliferative effects on multi-cellular tumor spheroids. N J Phys 16: 043027.

Robert E, Vandamme M, Brullé L, Lerondel S, Le Pape A, Sarron V, Riès D, Darny T, Dozias S, Collet G, Kieda C, Pouvesle JM (2013) Perspectives of endoscopic plasma applications. Clin Plasma Med 1: 8-16.

Sanchez-Ortiz RF, Tannir N, Ahrar K, Wood CG (2003) Spontaneous regression of pulmonary metastases from renal cell carcinoma after radio frequency ablation of primary tumor: an in situ tumor vaccine? J Urol 170: 178-179.

Sharman WM, Allen CM, Van Lier JE (1999) Photodynamic therapeutics: basic principles and clinical applications. Drug Discov Today 4: 507-517.

Sousa JS, Niemi K, Cox LJ, Algwari QT, Gans T, O'connell D (2011) Cold atmospheric pressure plasma jets as sources of singlet delta oxygen for biomedical applications. J Appl Phys 109: 123302.

Sturmey RG, Hawkhead JA, Barker EA, Leese HJ (2009) DNA damage and metabolic activity in the preimplantation embryo. Hum Reprod 24: 81-91.

Sullivan KF, Crawford ED (2009) Targeted focal therapy for prostate cancer: a review of the literature. Ther Adv Urol 1: 149-159.

Vandamme M, Robert E, Lerondel S, Sarron V, Ries D, Dozias S, Sobilo J, Gosset D, Kieda C, Legrain B, Pouvesle JM, Pape AL (2012) ROS implication in a new antitumor strategy based on non-thermal plasma. Int J Cancer 130: 2185-2194.

Voll RE, Herrmann M, Roth EA, Stach C, Kalden JR, Girkontaite I (1997) Immunosuppressive effects of apoptotic cells. Nature 390: 350-351.

Wagenaars E, Gans T, O'connell D, Niemi K (2012) Two-photon absorption laser-induced fluorescence measurements of atomic nitrogen in a radio-frequency atmospheric-pressure plasma jet. Plasma Sources Sci Technol 21: 042002.

Wang M, Holmes B, Cheng X, Zhu W, Keidar M, Zhang LG (2013) Cold atmospheric plasma for selectively ablating metastatic breast cancer cells. PLoS One 8: e73741.

Waskoenig J, Niemi K, Knake N, Graham LM, Reuter S, Schulz-Von Der Gathen V, Gans T (2010) Atomic oxygen formation in a radio-frequency driven micro-atmospheric pressure plasma jet. Plasma Sources Sci Technol 19: 045018.

Wiseman H, Halliwell B (1996) Damage to DNA by reactive oxygen and nitrogen species: role in inflammatory disease and progression to cancer. Biochem J 313(Pt 1): 17-29.

Woo JA, Chen LN, Bhagat A, Oermann EK, Kim JS, Moures R, Yung T, Lei S, Collins BT, Kumar D, Suy S, Dritschilo A, Lynch JH, Collins SP (2014) Clinical characteristics and management of late urinary symptom flare following stereotactic body radiation therapy for prostate cancer. Front Oncol 4: 122.

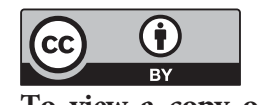

This work is licensed under the Creative Commons Attribution 4.0 International License. To view a copy of this license, visit http://creativecommons.org/ licenses/by/4.0/ 